\title{
ANALYSIS OF RELIABILITY POWER SUPPLY INTRUSION AND HOLD-UP SYSTEMS PRESENTED IN THE STANDARD PN-EN 50131-1:2009
}

\author{
ANALIZA NIEZAWODNOŚCIOWA UKŁADÓW \\ ZASILANIA SYSTEMÓW SYGNALIZACJI WLAMANIA \\ I NAPADU PRZEDSTAWIONYCH W NORMIE \\ PN-EN 50131-1:2009
}

\section{Malgorzata Pędzierska, Adam Rosiński}

Politechnika Warszawska, Wydział Transportu Warsaw University of Technology, Faculty of Transport

\begin{abstract}
The intrusion and hold-up system is one of the electronic security systems. The purpose of its application is to increase the level of safety for persons and property. This kind of solutions are used in all types of objects belonging to the critical infrastructure of the State. The article presents considerations for analysis reliability of intrusion and hold-up systems. Characterize them, taking into account the guidance contained in the standard "PN-EN50131-1:2009:Alarm systemsIntrusion and hold-up systems- part 1: System requirements". Then performed an analysis of reliability that enable their comparison. In further research of this issue is planned to carry out similar analyses, but for systems of access control and video surveillance systems (also distributed structures).
\end{abstract}

Keywords: reliability, power supply, intrusion and hold-up systems

Streszczenie: Jednym z elektronicznych systemów zabezpieczeń jest system sygnalizacji włamania i napadu. Celem jego stosowania jest zwiększenie poziomu bezpieczeństwa osobom i mieniu. Rozwiąania tego typu sa stosowane w różnego rodzaju obiektach zaliczanych do infrastruktury krytycznej państwa. W artykule zaprezentowano zagadnienia dotyczace analizy niezawodnościowej uktadów zasilania systemów sygnalizacji włamania $i$ napadu. Scharakteryzowano je $z$ uwzględnieniem wytycznych zawartych $w$ normie „PN-EN 50131-1:2009: Systemy alarmowe - Systemy sygnalizacji włamania $i$ napadu - Część 1: Wymagania systemowe”. Następnie dokonano analizy niezawodnościowej, które umożliwiaja ich porównanie. $W$ dalszych badaniach tego zagadnienia planuje sie dokonanie podobnych analiz, ale dla systemów kontroli dostępu $i$ systemów monitoringu wizyjnego (takie o strukturach rozproszonych).

Stowa kluczowe: niezawodność, zasilanie, system sygnalizacji włamania i napadu 
Analysis of reliability power supply intrusion and hold-up systems...

Analiza niezawodnościowa układów zasilania systemów sygnalizacji włamania...

\section{ANALYSIS OF RELIABILITY POWER SUPPLY INTRUSION AND HOLD-UP SYSTEMS PRESENTED IN THE STANDARD PN-EN 50131-1:2009}

\section{Introduction}

In the document "National Critical Infrastructure Protection Program" in the Republic of Poland, which was developed by the Government Security Center, 11 systems were included in the critical infrastructure [5]. Their proper functioning is important for our country. The tasks they carry out are designed to ensure the continuity functioning of their administrative structures and maintain a certain level of security for their citizens, protecting them from all sorts of threats. Among the mentioned systems is Transport [9]. It is therefore important to ensure the safety of transport objects (both stationary and mobile). This article has paid particular attention to the power supply systems for electronic safety systems. The authors have analyzed in detail the systems used in intrusion and robbery systems.

A full electronic security protection system is created from the following distinguished systems, depending on the detected threats, as systems:

- burglary and robbery alarms,

- fire signaling,

- access control,

- video monitoring,

- protection of external areas.

The protection resulting from the operation of these systems can be supplemented by the following systems:

- health or personal danger signalling,

- signalling environmental hazards,

- anti-theft,

- audible warning systems,

- car security against burglary and abduction.

One of the most important elements of the mentioned electronic security systems are alarm transmission systems. They consist of teleinformatic devices and networks $[16,24]$ used to transmit information of the state of one or more security systems to one or more alarm reception centers (eg, safety management centers).

In the face of the numerous and diverse threats (including terrorist) present in the transport process, it is important that the integrated security system counteract them as far as possible. At the same time, the reliability and operational indicators of the systems used should be reasonable $[4,11,15]$, adequately to the protected objects and their contents.

The level of security provided by the electronic safety systems of transport objects as critical infrastructure objects depends not only on the effectiveness of the particular security systems used $[7,10,21,27]$ but also on the proper functioning of the power supply systems (including electromagnetic interference $[13,18]$ ). 
Therefore, the authors have described the functioning of this type of systems in accordance with the guidelines contained in PN-EN 50131-1:2009 "Alarm systems - Burglary and panic alarm systems - System requirements".

Reliability issues in power systems are considered in both domestic and international literature for many years. Under item [2] are presented issues related to reliability of energy systems. The relationship between the reliability of the systems under consideration and the financial commitment to increase its value is shown. There are also various models of system reliability including damage intensity and repair intensity. This report also presents a reliability graph showing full ability and unreliability status and a graph showing additionally the state of foreclosure from the operation of the entire system.

The use of standby power sources is reported in $[25,26]$. These developments have highlighted the emergency power systems that are so often used to improve the readiness of the entire system. Solutions in the form of UPS uninterruptible power supplies, power generators as well as ecological solutions in the form of solar panels or wind power generators have been analyzed. An analysis of this kind of solutions has made it possible to conclude that their application allows to increase the value of reliability and exploitation parameters. Of course, properly designed systems switching control between the power sources used are essential.

Several important criteria are required from power supplies used in electronic safety systems, and in particular in transport systems used in safety,. The most important of them include, among others high efficiency, miniaturization, proper functionality, appropriate values of reliability and operational indicators $[1,17,19]$, ability to diagnose in particular operating conditions with regard to quality of information [23], electromagnetic immunity [6,12] and vibration [3]. Meeting these expectations requires knowledge of reliable reliability and operation models of power systems.

Despite analyzes of the reliability of power supply systems, it seems necessary to consider the functional analysis of power supply systems for electronic safety systems. This approach has already been partially presented in numerous studies by the authors of this article, but there is still no comprehensive analysis taking into account the guidelines contained in PN-EN 50131-1:2009.

\section{Characteristics of intrusion and hold-up systems power supply systems according to PN-EN 50131-1:2009 standard}

Power supply systems in intrusion and hold-up systems are very important. Switching to a state of unreliability or even partial unreliability is a failure of the entire alarm system, whose effects may be unpredictable in the event of a crisis situation. Simultaneous failure of both primary and backup power causes unreliability of the alarm system. The condition of failure one of them is also a major threat in the work of intrusion and hold-up systems. Such events should be promptly signalized to the appropriate users (eg, in the keypad of the failure message and its type) or to the services (eg information sent to the alarm receiving center). 
Analysis of reliability power supply intrusion and hold-up systems...

Analiza niezawodnościowa układów zasilania systemów sygnalizacji włamania...

The alarm system, depending on the construction solutions used and the degree of protection, requires a certain type of power supply. It is implemented by means of a set of devices $[8,14,20]$ :

- a power supply unit providing basic power and switching the power supply to a backup source in the event of a main power failure (usually also controlling the charging and operation of the backup power supply),

- battery, usually in the form of a rechargeable, chemical source of energy (usually gel batteries).

In alarm systems, the basic functions of the power supply system are implemented by the control panel of the system, which is an integral part of the power supply. The power supply is a part of the "electronics" that controls the burglary and robbery system and together with the battery most often comes in one housing.

The backup source used as the emergency power supply of the control panels is the battery. Its capacity should be carefully calculated in the so-called energy balance. The battery should ensure proper functioning of the control panel and its equipment at the required watch time and alarm time.

Currently the norm in Poland is the result of Poland's accession to the European Union. This is a translation of CENELEC European Standard for Electrotechnical Standardization (CENELEC): "EN 50131-1:2006" Alarm systems - Intrusion and hold-up systems - Part 1: System requirements ". It was adopted in Poland in 2009 as: „Norma PN-EN 50131-1:2009 Systemy alarmowe - Systemy sygnalizacji włamania i napadu - Wymagania systemowe".

According to the standard "EN 50131-1:2009: Alarm systems - Intrusion alarm systems - System requirements" [22] the following types of power supplies used in intrusion and hold-up systems are distinguished:

- type A: primary power source and backup power source that is controlled and charged by the burglar and attack signalling system (e.g primary power supply AC mains supply $230 \mathrm{~V} \mathrm{AC}$, backup power source - rechargeable battery by Intrusion and hold-up systems),

- type B: primary power source and backup power source that is not recharged by intrusion and intrusion alarm system (e.g primary power supply - AC mains supply $230 \mathrm{~V}$ AC, backup power supply - rechargeable battery not recharged) By Intrusion and hold-up systems),

- type C: primary source of finite power (e.g battery).

Figure 1 shows the power supply type A. It is characterized by the presence of a power source that is used to power the intrusion and hold-up systems or its part under normal operating conditions. The security system controls the battery status and automatically recharges it when needed. This is illustrated by the dashed line between the safety system and the standby power supply (battery). In case of recharging the current flows from the safety system to the battery. On the other hand, if the mains power goes out ( $230 \mathrm{~V} \mathrm{AC})$, it automatically switches to the backup source and the current flows from the battery to the safety system. 
Małgorzata Pędzierska, Adam Rosiński

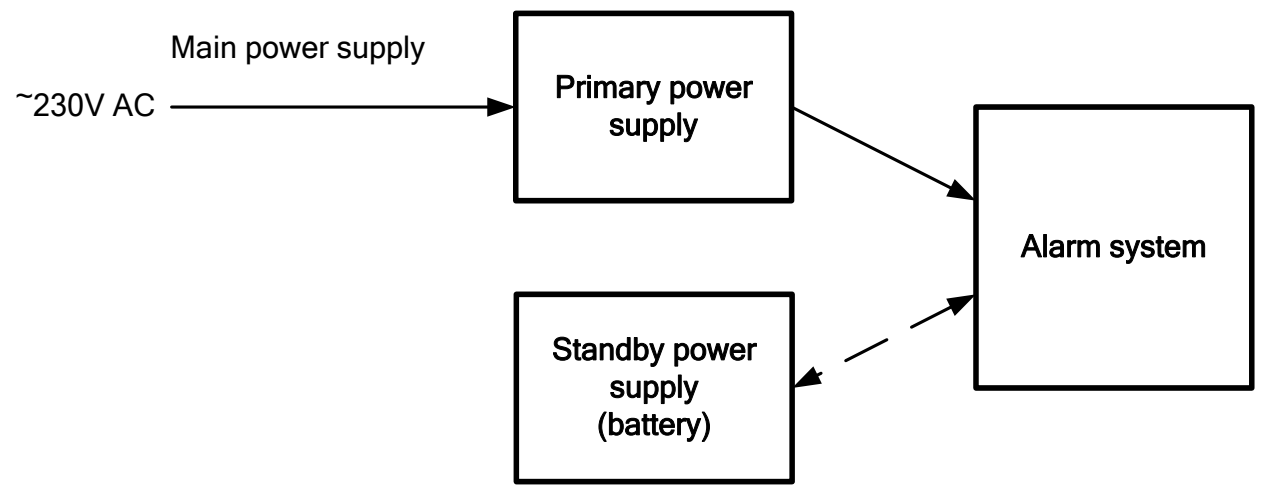

Fig. 1 Example of A type power supply of alarm system [source: own development]

Figure 2 shows the B-type power supply. It is characterized by the presence of a primary source that is used to power the intrusion and hold-up systems or its part under normal operating conditions.

a)

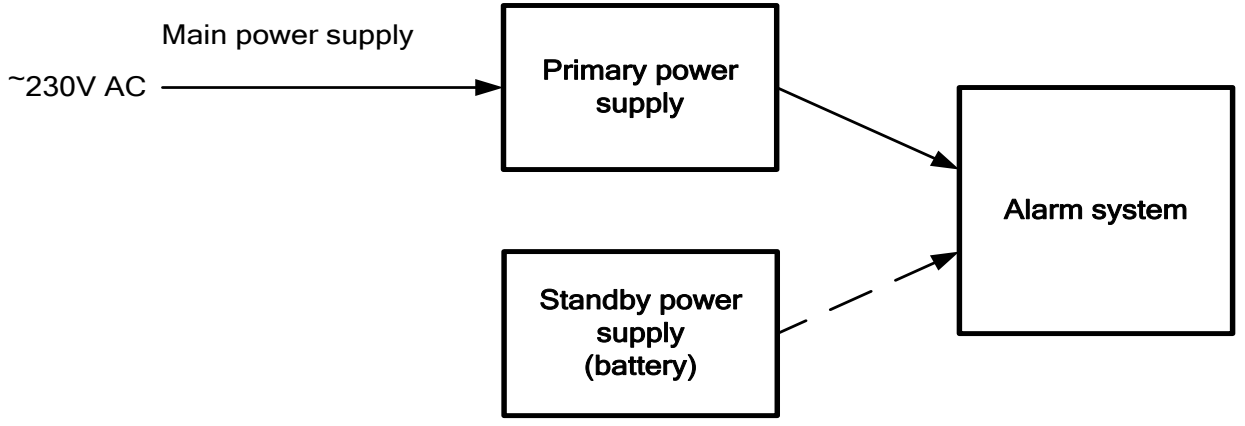

b)

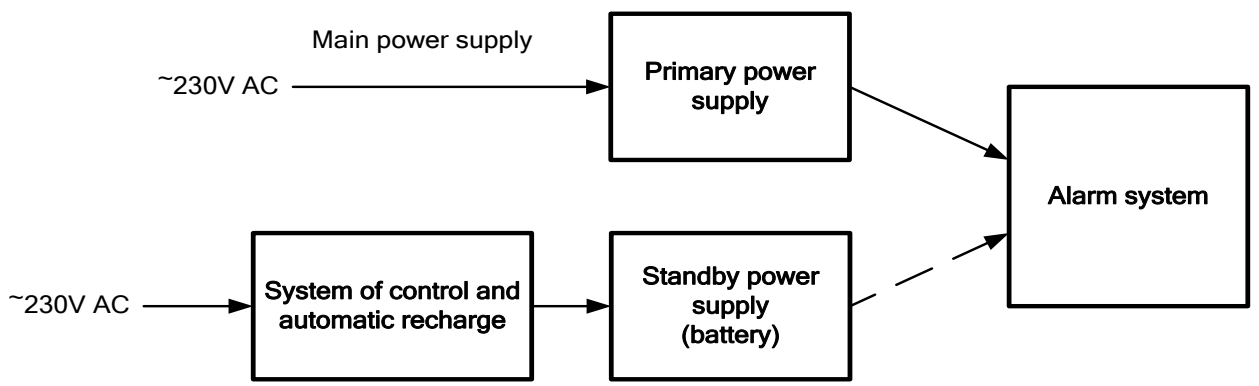

Fig. 2 Example of B type power supply of alarm system:

a) in the absence of recharging the backup battery (battery),

b) control and automatic recharging of the backup battery (source)

[source: own study] 
Analysis of reliability power supply intrusion and hold-up systems...

Analiza niezawodnościowa układów zasilania systemów sygnalizacji włamania...

In the event of a mains power failure $(\sim 230 \mathrm{~V} \mathrm{AC})$ it automatically switches to a backup source and the current flows from the battery to the alarm system (Figure 2a). The battery is not recharged in any way by the alarm system. However, it is possible to configure the Intrusion and hold-up systems devices (fig. 2b), which has a control and automatic recharge system, but it is not a component of the control panel.

Figure 3 shows the C-type power supply. It is characterized by the presence of a finite-element power source (battery) that is used to power the intrusion and holdup systems. This solution requires the designer to use properly selected batteries because in the event of a drop below the required voltage, the alarm system ceases to function and perform the tasks for which it was designed.

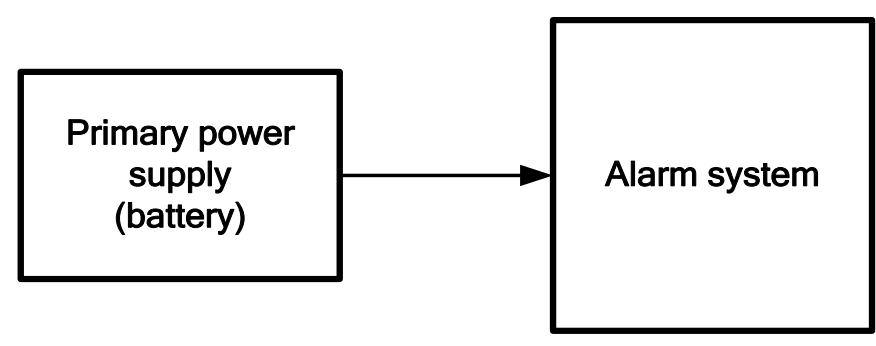

Fig. 3 Example of $C$ type power supply of alarm system [source: own development]

Power Supplies used in intrusion and hold-up systems should have appropriate documentation that they meet certain requirements and criteria. Therefore, the manufacturers of these devices are testing them to determine whether they meet the requirements. One of the documents containing guidance on the parameters included in the Polish standard "EN 50131-6:2009: Alarm systems intrusion and hold-up systems - Part 6: Power supply". Included in it are, among others. Required power supply system functions depending on the type of power supply and the degree of protection. For example, it can be stated that for power supply type B and 4 stages the power supply should be:

- detect no external power source,

- detect low battery voltage,

- detect battery damage,

- detect low input voltage,

- protect against overvoltage,

- protect against short-circuit,

- protect against overload,

- protect against full discharge of the battery. 


\section{Reliability and operational analysis of intrusion and hold-up systems power supply systems}

When analyzing the reliability and operation of Intrusion and hold-up systems power supply systems, specific criteria for their evaluation should be adopted. This can be a function of reliability, damage density, damage intensity, etc. The authors, however, have decided to take the readiness indicator as it allows for restoration activities to be considered for power systems. In general, the readiness indicator can be written:

$$
K_{g}=\frac{T_{m}}{T_{m}+T_{n}}
$$

where: $T_{m}$ - average time of correct operation between failures,

$\mathrm{T}_{\mathrm{n}}$ - average repair time.

From the depicted relationship, the power supply may be in one of two states (Figure 4):

- state of use $\left(\mathrm{S}_{0}\right)$,

- state of repair $\left(\mathrm{S}_{1}\right)$.

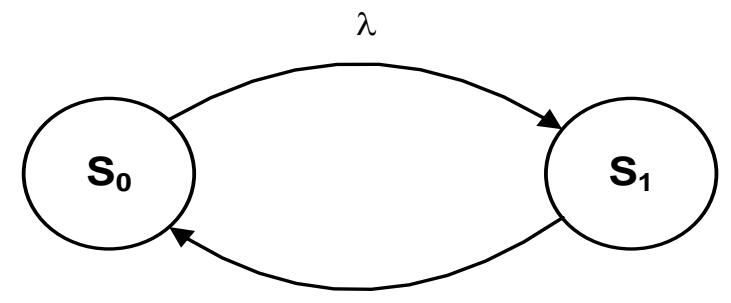

$\mu$

Fig. 4 Relationships in the C type power supply

Markings in Fig.4: $\lambda$ - damage intensity, $\mu$ - repair intensity

[source: own development]

The model shown in Fig. 4 maps the operation of the C-type power supply, assuming that no diagnostic actions are directly related to the power state of the battery. In the case of diagnosis of its condition, the model shown in Fig. 4 will have the following form - Fig. 5.

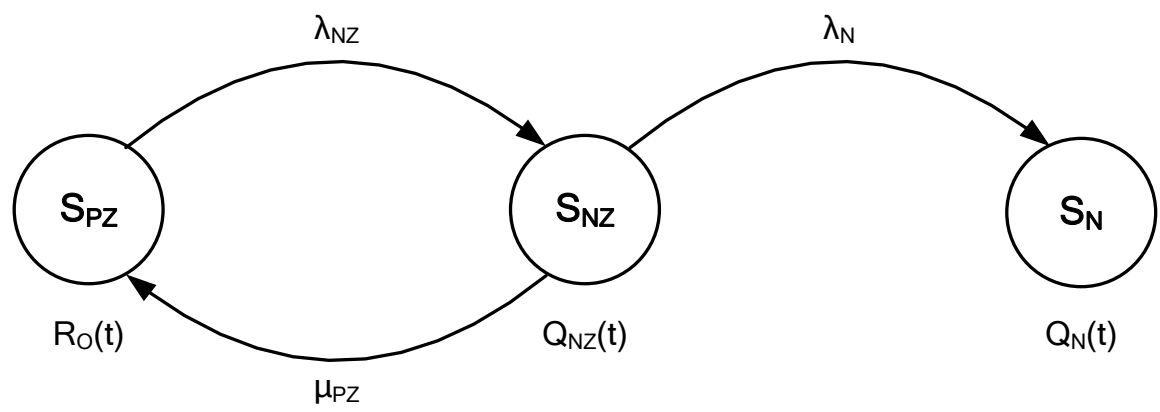

Fig. 5 Relationships in the C-type power supply for diagnosing the battery 
Analysis of reliability power supply intrusion and hold-up systems...

Analiza niezawodnościowa układów zasilania systemów sygnalizacji włamania...

Markings in Fig.5: $R_{O}(t)$ - the probability function of the system's staying in the state of full ability, $Q_{N Z}(t)$ - the probability function of the system's staying in the state of partial ability, $Q_{N}(t)$ - the probability function of the system's staying in the state of full unreliability, $\lambda_{N Z}$ - intensity of transitions from the state of full ability to the state of partial ability, $\mu_{P Z}-$ intensity of transitions from the state of partial ability to the state of full ability, $\lambda_{N}$ - intensity of transitions from the state of partial ability to the state of full unreliability[source: own development]

By analyzing the model shown in Figure 5, it can be stated that when the system diagnose partial ability of battery, the UPS goes from the state of full ability to the state of partial ability $S_{N Z}$. Replacing the battery by the user results in a return to full ability. If there is a $S_{N Z}$ state and no battery recycle action occurs, then after a certain period of time, the UPS goes to the unrecoverable state of the UPS.

The system shown in Figure 5 can be described by the following KolmogorovChapman equations:

$$
\begin{aligned}
& R_{0}^{\prime}(t)=-\lambda_{N Z} \cdot R_{0}(t)+\mu_{P Z} \cdot Q_{N Z}(t) \\
& Q_{N Z}^{\prime}(t)=\lambda_{N Z} \cdot R_{0}(t)-\mu_{P Z} \cdot Q_{N Z}(t)-\lambda_{N} \cdot Q_{N Z}(t) \\
& Q_{N}^{\prime}(t)=\lambda_{N} \cdot Q_{N Z}(t)
\end{aligned}
$$

The considerations discussed in this chapter are related to the Type $\mathrm{C}$ power supply. When considering the operation of the Type A power supply, the relationship graph will have a more complex form (more states) because there are two independent sources of power: primary and backup. So, after analysis, you can propose a graph of the relationship in the power supply type A as shown in Figure 6.

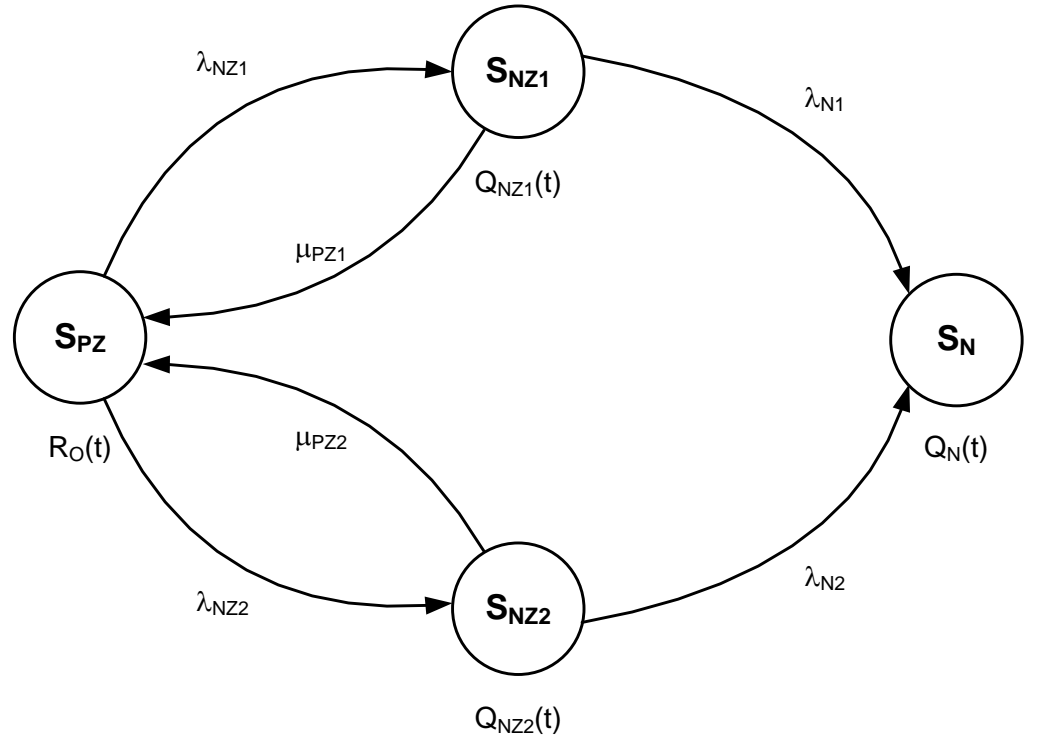

Fig. 6 Relationships in the A-type power supply 
Markings in Fig.6: $R_{O}(t)$ - the probability function of the system's staying in the state of full ability, $Q_{N Z 1}(t)$ - the probability function of the power supply's staying in the state of partial ability $1, Q_{N Z 2}(t)$ - the probability function of the power supply's staying in the state of partial ability $2, Q_{N}(t)$ - the probability function of the power supply's staying in the state of full unreliability, $\lambda_{N Z 1}, \lambda_{N Z 2}-$ intensity of transitions from the state of full ability to the state of partial ability, $\mu_{P Z 1,} \mu_{P Z 2}-$ intensity of transitions from the state of partial ability to the state of full ability, $\lambda_{N 1}, \lambda_{N 2}$ - intensity of transitions from the state of full ability to the state of partial ability [source: own development]

Failure of the primary power source results in the transition from full ability to partial ability of $S_{\mathrm{NZ}}$. Restoration of the mains supply condition results in the change from the state of partial ability of $\mathrm{S}_{\mathrm{NZ} 1}$ to the state of full ability of the SpZ. In the event that the power supply system of type $A$ is in the state of $S_{\mathrm{NZ} 1}$ and damage to the standby power supply occurs, then the transition to the state of $\mathrm{S}_{\mathrm{N}}$ inactivity proceeds.

Damage to the standby power source causes the transition from the state of the full ability $\mathrm{S}_{\mathrm{PZ}}$ to the state of partial ability $\mathrm{S}_{\mathrm{NZ}}$. Restoration of the standby state of the backup power causes the transition from the state of incomplete ability of $S_{\mathrm{NZ}}$. to the state of full ability of the $S_{\mathrm{PZ}}$. In the event that the power supply system of type $\mathrm{A}$ is in the state of $\mathrm{S}_{\mathrm{NZ2}}$ and damage to the primary power source, then the transition to the state of $S_{N}$ inactivity proceeds.

The system shown in Figure 6 can be described by the following KolmogorovChapman equations:

$$
\begin{aligned}
& R_{0}^{\prime}(t)=-\lambda_{N Z 1} \cdot R_{0}(t)+\mu_{P Z 1} \cdot Q_{N Z 1}(t)-\lambda_{N Z 2} \cdot R_{0}(t)+\mu_{P Z 2} \cdot Q_{N Z 2}(t) \\
& Q_{N Z 1}^{\prime}(t)=\lambda_{N Z 1} \cdot R_{0}(t)-\mu_{P Z 1} \cdot Q_{N Z 1}(t)-\lambda_{N 1} \cdot Q_{N Z 1}(t) \\
& Q_{N Z 2}^{\prime}(t)=\lambda_{N Z 2} \cdot R_{0}(t)-\mu_{P Z 2} \cdot Q_{N Z 2}(t)-\lambda_{N 2} \cdot Q_{N Z 2}(t) \\
& Q_{N}^{\prime}(t)=\lambda_{N 1} \cdot Q_{N Z 1}(t)+\lambda_{N 2} \cdot Q_{N Z 2}(t)
\end{aligned}
$$

Considering the operation of the B-type power supply, the graph of the relationship will have the form shown in Figure 7. In this situation, the alarm system does not diagnose the backup power source and therefore its technical condition (eg voltage, charge level, operating temperature) is unknown. Thus, there is the possibility of a direct transition from a state of full ability to a state of unreality. 
Analysis of reliability power supply intrusion and hold-up systems...

Analiza niezawodnościowa układów zasilania systemów sygnalizacji włamania...

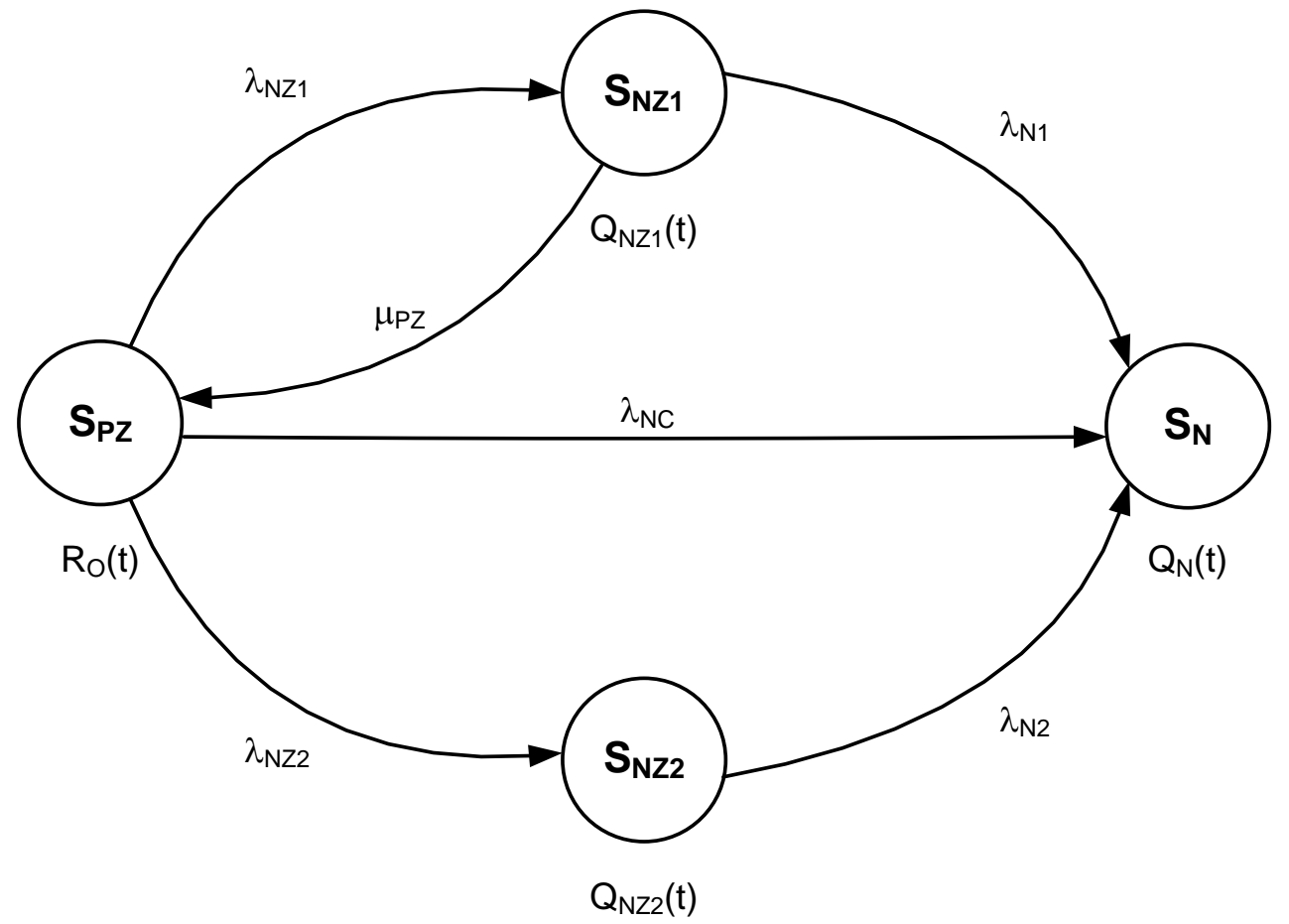

Fig. 7 Relationships in the B-type power supply

Markings in Fig.7: $R_{O}(t)$ - the probability function of the system's staying in the state of full ability, $Q_{N Z 1}(t)$ - the probability function of the power supply's staying in the state of partial ability $1, Q_{N Z 2}(t)$ - the probability function of the power supply's staying in the state of partial ability $2, Q_{N}(t)$ - the probability function of the power supply's staying in the state of full unreliability, $\lambda_{N Z 1}, \lambda_{N Z 2}-$ intensity of transitions from the state of full ability to the state of partial ability, $\mu_{P Z}-$ intensity of transitions from the state of partial ability 1 to the state of full ability, $\lambda_{N 1}, \lambda_{N 2}-$ intensity of transitions from the state of full ability to the state of partial ability, $\lambda_{N C}$ - intensity of transitions from the state of full ability to the state of unreliability [source: own development]

Failure of the primary power source results in the transition from full ability to full ability of $S_{\mathrm{NZ1}}$. Restoration of the mains supply condition results in the change from the state of incompleteness of SNZ1 to the state of full ability of the Spz. In the event that the power supply of the B-type power supply is in the state of $S_{\mathrm{NZ} 1}$ and damage to the standby power supply occurs, then the $\mathrm{S}_{\mathrm{N}}$ becomes unstable.

Damage to the standby power source (with proper mains supply) results in the transition from fully operational state of the SPZ to the state of partial ability SNZ2. In the absence of diagnosis of the standby power source, it is not possible to switch from the state of partial ability of SNZ2 to the state of full ability SPZ. 
In the event that the power supply of the B-type power supply is in the state of SNZ2 and damage to the primary power source, then the system becomes unreliability. Damage to the standby power supply (with unsuitable primary supply) results in a direct transition from the fully functional state of the Spz to the state of the unreliability $\mathrm{S}_{\mathrm{N}}$.

The system shown in Figure 7 can be described by the following KolmogorovChapman equations:

$$
\begin{aligned}
& R_{0}^{\prime}(t)=-\lambda_{N Z 1} \cdot R_{0}(t)+\mu_{P Z} \cdot Q_{N Z 1}(t)-\lambda_{N Z 2} \cdot R_{0}(t)-\lambda_{N C} \cdot R_{0}(t) \\
& Q_{N Z 1}^{\prime}(t)=\lambda_{N Z 1} \cdot R_{0}(t)-\mu_{P Z} \cdot Q_{N Z 1}(t)-\lambda_{N 1} \cdot Q_{N Z 1}(t) \\
& Q_{N Z 2}^{\prime}(t)=\lambda_{N Z 2} \cdot R_{0}(t)-\lambda_{N 2} \cdot Q_{N Z 2}(t) \\
& Q_{N}^{\prime}(t)=\lambda_{N 1} \cdot Q_{N Z 1}(t)+\lambda_{N 2} \cdot Q_{N Z 2}(t)+\lambda_{N C} \cdot R_{0}(t)
\end{aligned}
$$

In the presented models of power supplies type A, B and C it was assumed that the condition of the failure is an absorption state. By comparing various types of manufacturer solutions and their use in real-world situations, this condition is not achieved by the alarm system.

Presented models of power supplies used in alarm systems can be used to determine dependencies that allow calculating the probability of staying in the

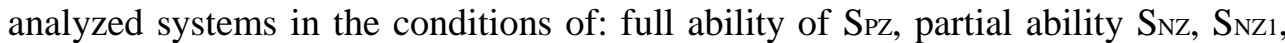
$\mathrm{S}_{\mathrm{NZ2}}$ and unreliability $\mathrm{S}_{\mathrm{N}}$. This will allow you to compare different types of solutions and rational choice with the criteria set.

\section{Summary}

The problem presented in the article is concerned on power supply systems of alarm systems. According to the guidelines contained in the standard "PN-EN 50131-1:2009: Alarm systems - intrusion and hold-up systems", three power supply types A, B and C were presented schematically. For each of them was performed analysis of reliability and a graph of relations. Further mathematical analysis will allow to calculate the probability of staying in a state of full ability, partial ability, and unreliability. In subsequent scientific considerations, the authors plan to carry out analysis and model development including the diagnosis process.

\section{References}

[1] Będkowski L., Dąbrowski T.: Basics of exploitation, vol. II Basic of operational reliability. Military University of Technology, Warsaw 2006.

[2] Billinton R., Allan R. N.: Reliability evaluation of power systems. New York: Plenum Press, 1996.

[3] Burdzik R., Konieczny Ł.: Research on structure, propagation and exposure to general vibration in passenger car for different damping parameters. Journal of Vibroengineering Vol. 15, Issue 4, 2013, pp. 1680-1688.

[4] Dyduch J., Paś J., Rosiński A.: The basis of the exploitation of transport electronic systems. Publisher Technical University of Radom, Radom 2011. 
Analysis of reliability power supply intrusion and hold-up systems...

Analiza niezawodnościowa układów zasilania systemów sygnalizacji włamania...

[5] Government Security Centre, National Programme for Critical Infrastructure Protection. Annex 1: Summary of critical infrastructure systems, Warsaw 2013.

[6] Kaniewski P., Lesnik C., Susek W., Serafin P.: Airborne Radar Terrain Imaging System. 16th International Radar Symposium (IRS), Dresden, Germany, 2015. pp. 248-253.

[7] Kierzkowski A., Kisiel T.: Airport security screeners reliability analysis. In: „Proceedings of the IEEE International Conference on Industrial Engineering and Engineering Management IEEM 2015”, Singapore 2015. pp. 1158-1163.

[8] Korczak D., Rosiński A.: A discussion of the reliability and performance of the power supply systems used in the airport security systems. In: the monograph „Wyzwania inżynierii ruchu lotniczego", editor: J. Skorupski, Warsaw University of Technology, Faculty of Transport, Warsaw 2016. pp. 129-137.

[9] Lewczuk K., Zak J., Pyza D., Jacyna-Gołda I.: Vehicle routing in an urban area: Environmental and technological determinants. WIT Transactions on the Built Environment, Vol.130, 2013. pp. 373-384.

[10] Lubkowski P, Laskowski D.: Selected issues of reliable identification of object in transport systems using video monitoring services. In: „Communication in Computer and Information Science”, editor: J. Mikulski, vol. 471. Springer, Berlin Hedelberg 2015. pp. 59-68.

[11] Paś J.: Operation of electronic transportation systems. Publishing House University of Technology and Humanities in Radom, Radom 2015.

[12] Paś J.: Shock a disposable time in electronic security systems. Journal of KONBiN, 2(38)2016. pp. 5-31.

[13] Paś J., Siergiejczyk M.: Interference impact on the electronic safety system with a parallel structure. Diagnostyka, Vol. 17, No. 1, 2016. pp. 49-55.

[14] Rosinski A., Dabrowski T.: Modelling reliability of uninterruptible power supply units. Eksploatacja i Niezawodnosc - Maintenance and Reliability, Vol.15, No. 4, 2013.pp. 409-413.

[15] Rosiński A.: Modelling the maintenance process of transport telematics systems. Publishing House Warsaw University of Technology, Warsaw 2015.

[16] Rychlicki M., Kasprzyk Z.: Increasing performance of SMS based information systems. In: „Proceedings of the Ninth International Conference Dependability and Complex Systems DepCoS-RELCOMEX", given as the monographic publishing series - „Advances in intelligent systems and computing”, Vol. 286. Springer, 2014. pp. 373-382.

[17] Siergiejczyk M., Krzykowska K., Rosiński A. Reliability assessment of integrated airport surface surveillance system. In „Proceedings of the Tenth International Conference on Dependability and Complex Systems DepCoSRELCOMEX”, given as the monographic publishing series - „Advances in intelligent systems and computing", vol. 365. Springer 2015. pp. 435-443.

[18] Siergiejczyk M., Paś J., Rosiński A.: Issue of reliability-exploitation evaluation of electronic transport systems used in the railway environment with consideration of electromagnetic interference. IET Intelligent Transport Systems 2016,vol. 10, issue 9, 2016, pp. 587-593. 
[19] Siergiejczyk M., Rosiński A., Krzykowska K.: Reliability assessment of supporting satellite system EGNOS. In: W. Zamojski, J. Mazurkiewicz, J. Sugier, T. Walkowiak, J. Kacprzyk (eds) New results in dependability and computer systems, given as the monographic publishing series - „Advances in intelligent and soft computing", Vol. 224. Springer, 2013. pp. 353-364.

[20] Siergiejczyk M., Rosiński A.: Analysis of power supply maintenance in transport telematics system. „Solid State Phenomena” vol. 210 (2014). pp. 14-19.

[21] Skorupski J., Uchroński P.: A fuzzy reasoning system for evaluating the efficiency of cabin luggage screening at airports. Transportation Research Part C - Emerging Technologies 54, 2015. pp. 157-175.

[22] Standard PN-EN 50131-1:2009: Alarm systems - Intrusion and hold-up systems - System requirements.

[23] Stawowy M., Dziula P.: Comparison of uncertainty multilayer models of impact of teleinformation devices reliability on information quality. In: "Proceedings of the European Safety and Reliability Conference ESREL 2015", editors: L. Podofillini, B. Sudret, B. Stojadinovic, E. Zio, W. Kröger. CRC Press/Balkema, 2015. pp. 2685-2691.

[24] Sumiła M., Miszkiewicz A.: Analysis of the problem of interference of the public network operators to GSM-R. In: the monograph „Tools of Transport Telematics",editors: J. Mikulski, given as the monographic publishing series „Communications in Computer and Information Science”, Vol. 531, Springer, 2015, pp. 76-82.

[25] Wiatr J., Miegoń M.: UPS power supplies and accumulator batteries in emergency power systems. Publishing House MEDIUM, Warsaw 2008.

[26] Wiatr J.: Generating sets in building emergency power systems. Publishing House MEDIUM, Warsaw 2009.

[27] Wiśnios M., Dąbrowski T., Bednarek M.: The security increasing level method provided by biometric access control system. Przegląd Elektrotechniczny 2015, no 10 , pp. 229-232.

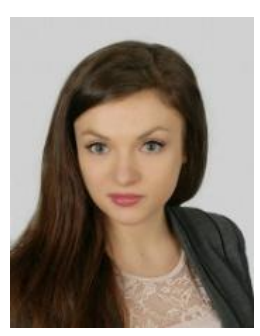

Matgorzata Pedzierska Eng.- scientific fields of interest of the paper co-author concern among the intelligent transport systems, their influence of traffic safety and reliability analysis of electronic safety systems (Share 50\%).

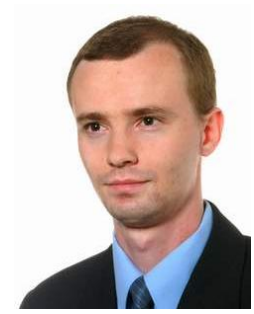

Assoc. Eng. Adam Rosiński - research interests include the analysis of reliability-exploitation transport systems telematics and intelligent transport systems. The scientific output has dozens of scientific publications (Share 50\%). 
Analysis of reliability power supply intrusion and hold-up systems...

Analiza niezawodnościowa układów zasilania systemów sygnalizacji włamania...

\section{ANALIZA NIEZAWODNOŚCIOWA UKŁADÓW ZASILANIA \\ SYSTEMÓW SYGNALIZACJI WLAMANIA I NAPADU PRZEDSTAWIONYCH W NORMIE PN-EN 50131-1:2009}

\section{Wstęp}

W dokumencie „Narodowy Program Ochrony Infrastruktury Krytycznej” w Rzeczypospolitej Polskiej, który został opracowany przez Rządowe Centrum Bezpieczeństwa, zostało wymienionych 11 systemów wchodzących w skład infrastruktury krytycznej [5]. Ich prawidłowe funkcjonowanie ma istotne znaczenie dla naszego kraju. Realizowane przez te systemy zadania, zapewniają ciągłość funkcjonowania struktur administracyjnych, jak też utrzymują określony poziom bezpieczeństwa obywateli, chroniąc ich przed różnego rodzaju zagrożeniami. Wśród wymienionych systemów znajduje się m.in. transport [9]. Dlatego też tak istotne jest zapewnienie bezpieczeństwa obiektom transportowym (zarówno stacjonarnym jak i ruchomym). W artykule zwrócono szczególną uwagę na układy zasilania elektronicznych systemów bezpieczeństwa. Autorzy szczegółowo dokonali analizy tych układów zastosowanych w systemach sygnalizacji włamania i napadu.

System pełnej ochrony elektronicznej zapewniającej bezpieczeństwo jest tworzony z następujących systemów wyróżnianych zależnie od wykrywanych zagrożeń, jako systemy:

- sygnalizacji włamania i napadu,

- sygnalizacji pożaru,

- kontroli dostępu,

- monitoringu wizyjnego,

- ochrony terenów zewnętrznych.

Ochrona wynikająca $\mathrm{z}$ funkcjonowania tych systemów może być uzupełniona przez systemy:

- sygnalizacji stanu zdrowia lub zagrożenia osobistego,

- sygnalizacji zagrożeń środowiska,

- przeciwkradzieżowe,

- dźwiękowe systemy ostrzegawcze,

- zabezpieczenia samochodów przed włamaniem i uprowadzeniem.

Jednym $\mathrm{z}$ istotniejszych elementem wymienionych elektronicznych systemów bezpieczeństwa są systemy transmisji alarmu. Składają się one m.in. z urządzeń i sieci teleinformatycznych [16,24], wykorzystywanych do przekazywania informacji o stanie jednego lub więcej systemów bezpieczeństwa do jednego lub kilku alarmowych centrów odbiorczych (np. centra zarządzania bezpieczeństwem). Wobec występujących obecnie licznych i różnorodnych zagrożeń (w tym terrorystycznych) w procesie transportowym istotne jest, by zintegrowany system bezpieczeństwa możliwie jak najszerzej im przeciwdziałał. 
Jednocześnie też wskaźniki niezawodnościowo-eksploatacyjne stosowanych systemów powinny być racjonalne $[4,11,15]$, adekwatnie do chronionych obiektów i ich zawartości.

Poziom bezpieczeństwa jaki zapewniają elektroniczne systemy bezpieczeństwa obiektów transportowych, jako obiektów zaliczanych do infrastruktury krytycznej, zależy nie tylko od skuteczności zastosowanych poszczególnych systemów bezpieczeństwa [7,10,21,27], ale także od prawidłowego funkcjonowania układów zasilających (także z uwzględnieniem zakłóceń elektromagnetycznych $[13,18]$ ). Dlatego też autorzy dokonali opisu funkcjonowania tego typu systemów zgodnie z wytycznymi zawartymi w normie PN-EN 50131-1:2009 „Systemy alarmowe Systemy sygnalizacji włamania i napadu - Wymagania systemowe".

Kwestie związane $\mathrm{z}$ niezawodnością $\mathrm{w}$ systemach zasilania są rozważane w pozycjach literaturowych zarówno krajowych jak i międzynarodowych już od wielu lat. W pozycji [2] przedstawiono zagadnienia związane $\mathrm{z}$ niezawodnością systemów energetycznych. Ukazano zależność pomiędzy niezawodnością rozpatrywanych systemów, a nakładami finansowymi przeznaczonymi na zwiększenie jej wartości. Zaprezentowano także różne modele niezawodnościowe systemów z uwzględnieniem intensywności uszkodzeń i intensywności napraw. $\mathrm{W}$ opracowaniu tym przedstawiono także graf niezawodnościowy zawierający stan zdatności i niezdatności oraz graf zawierający dodatkowo stan wykluczenia urządzenia z pracy całego systemu.

Zastosowanie rezerwowych źródeł zasilania przedstawiono w publikacjach $[25,26]$. W opracowaniach tych szczególną uwagę zwrócono na systemy zasilania awaryjnego, które są obecnie tak często stosowane w celu zwiększenia poziomu gotowości całego systemu. Przeanalizowano rozwiązania w postaci: zasilaczy bezprzerwowych UPS, zespołów prądotwórczych, a także ekologiczne rozwiązania w postaci paneli solarnych czy generatorów prądu napędzanych siłą wiatru. Dokonana analiza tego rodzaju rozwiązań pozwoliła stwierdzić, iż zastosowanie ich pozwala na zwiększenie wartości wskaźników niezawodnościowoeksploatacyjnych. Oczywiście niezbędne są prawidłowo zaprojektowane układy sterujące przełączaniem pomiędzy zastosowanymi źródłami energii elektrycznej.

Od zasilaczy stosowanych w elektronicznych systemach bezpieczeństwa, a w szczególności w zastosowanych w transportowych systemach bezpieczeństwa wymaga się spełnienia wielu istotnych kryteriów. Do najistotniejszych z nich można zaliczyć $\mathrm{m}$. in. wysoką sprawność, miniaturyzację, odpowiednią funkcjonalność, odpowiednie wartości wskaźników niezawodnościowoeksploatacyjnych $[1,17,19]$, możliwość diagnozowania w poszczególnych stanach eksploatacyjnych z uwzględnieniem jakości informacji [23], odporność na zakłócenia elektromagnetyczne [6,12] i wibracje [3]. Spełnienie tych oczekiwań wymaga znajomości wiarygodnych modeli niezawodnościowo-eksploatacyjnych systemów zasilających.

Pomimo przeprowadzonych analiz z zakresu niezawodności systemów zasilania, wydaje się konieczne przeprowadzenie rozważań z zakresu analizy funkcjonalnej układów zasilających elektroniczne systemy bezpieczeństwa. 
Analysis of reliability power supply intrusion and hold-up systems...

Analiza niezawodnościowa układów zasilania systemów sygnalizacji włamania...

Tego typu podejście zostało już częściowo zaprezentowane w licznych opracowaniach autorów niniejszego artykułu, ale brak jest nadal kompleksowej analizy z uwzględnieniem wytycznych zawartych w normie PN-EN 50131-1:2009.

\section{Charakterystyka układów zasilania SSWiN według normy PN-EN 50131-1:2009}

Układy zasilania w Systemach Sygnalizacji Włamania i Napadu (SSWiN) spełniają bardzo istotną rolę. Przejście ich w stan niezdatności lub nawet w stan częściowej niezdatności stanowi uchybienie $\mathrm{w}$ pracy całego systemu alarmowego, którego skutki mogą być nieprzewidywalne w przypadku wystąpienia sytuacji kryzysowej. Jednoczesna awaria zarówno zasilania podstawowego, jak i rezerwowego powoduje całkowitą niezdatność systemu alarmowego. Stan niezdatności jednego $\mathrm{z}$ nich stanowi także duże zagrożenie $\mathrm{w}$ pracy SSWiN. Tego rodzaju zdarzenia powinny być bezzwłocznie sygnalizowane odpowiednim użytkownikom (np. w manipulatorze komunikat o awarii i jej rodzaju) lub służbom (np. informacja przekazana do alarmowego centrum odbiorczego).

System alarmowy, zależnie od zastosowanych rozwiązań konstrukcyjnych i stopnia zabezpieczenia, wymaga określonego rodzaju zasilania. Jest ono realizowane za pomocą zespołu urządzeń, w skład których można zaliczyć $[8,14,20]$ :

- urządzenia zasilającego, zapewniającego zasilanie podstawowe oraz przełączenie zasilania na rezerwowe źródło w przypadku zaniku zasilania głównego (najczęściej także kontroluje ładowanie i obsługę rezerwowego źródła zasilania),

- akumulatora, zwykle w postaci ładowalnego, chemicznego źródła energii (najczęściej akumulatorów żelowych).

W systemach alarmowych podstawowe funkcje z zakresu układu zasilania realizuje centrala alarmowa systemu, której integralną częścią jest zasilacz. Urządzenie zasilające jest częścią „elektroniki” sterującej systemem sygnalizacji włamania i napadu i wraz z akumulatorem najczęściej znajduje się w jednej obudowie.

Źródłem rezerwowym stosowanym jako zasilanie rezerwowe central alarmowych jest akumulator. Jego pojemność powinna być starannie obliczona w tzw. bilansie energetycznym. Akumulator powinien gwarantować poprawne funkcjonowanie centrali alarmowej i zasilanych z niej urządzeń w wymaganym czasie dozorowania i czasie trwania stanu alarmowania.

Obecnie w Polsce obowiązuje norma wynikają z wstąpienia Polski do Unii Europejskiej. Jest to thumaczenie normy europejskiej opracowanej przez European Committee for Electrotechnical Standardization CENELEC: „EN 50131-1:2006 „Alarm systems - Intrusion and hold-up systems - Part 1: System requirements”. Została ona w Polsce przyjęta w 2009 r. jako: „Norma PN-EN 50131-1:2009 Systemy alarmowe - Systemy sygnalizacji włamania i napadu - Wymagania systemowe". 
Według normy „PN-EN 50131-1:2009: Systemy alarmowe - Systemy sygnalizacji włamania i napadu - Wymagania systemowe" [22] wyróżnia się następujące typy zasilaczy stosowanych w SSWiN:

- typ A: podstawowe źródło zasilania i rezerwowe źródło zasilania, które jest kontrolowane i doładowywane przez system sygnalizacji włamania i napadu (np. podstawowe źródło zasilania - zasilanie z sieci energetycznej prądem przemiennym o napięciu $230 \mathrm{~V}$ AC, rezerwowe źródło zasilania - akumulator doładowywany przez SSWiN),

- typ B: podstawowe źródło zasilania i rezerwowe źródło zasilania, które nie jest doładowywane przez system sygnalizacji włamania i napadu (np. podstawowe źródło zasilania - zasilanie $\mathrm{z}$ sieci energetycznej prądem przemiennym o napięciu 230V AC, rezerwowe źródło zasilania - akumulator, który nie jest doładowywany przez SSWiN),

- typ C: podstawowe źródło zasilania o skończonej pojemności (np. bateria).

Na rys. 1 przedstawiono zasilacz typu A. Cechuje się on występowaniem źródła podstawowego, który jest wykorzystywany do zasilania SSWiN lub jego części w normalnych warunkach pracy. System bezpieczeństwa kontroluje stan akumulatora i w razie konieczności automatycznie go doładowuje. Zobrazowane jest to przy pomocy linii przerywanej pomiędzy systemem bezpieczeństwa a zasilaczem rezerwowym (akumulatorem). W przypadku doładowywania prąd płynie $\mathrm{z}$ systemu bezpieczeństwa do akumulatora. Natomiast $\mathrm{w}$ razie zaniku zasilania podstawowego ( 230 V AC) następuje automatyczne przełączenie na źródło rezerwowe i prąd płynie $\mathrm{z}$ akumulatora do systemu bezpieczeństwa.

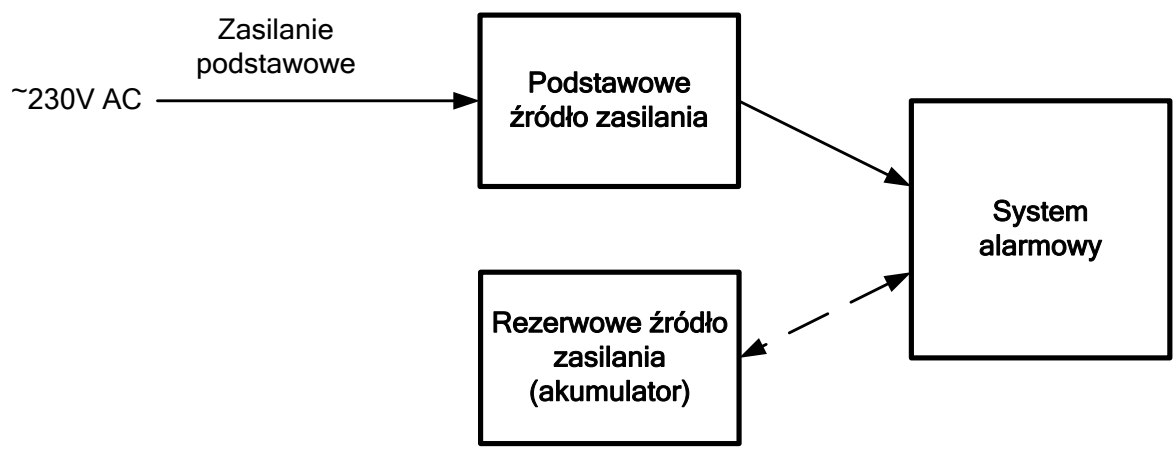

Rys. 1 Przykład zasilacza typu A systemu alarmowego [źródto: opracowanie własne]

Na rys. 2 przedstawiono zasilacz typu B. Cechuje się on występowaniem źródła podstawowego, który jest wykorzystywany do zasilania SSWiN lub jego części w normalnych warunkach pracy. W przypadku zaniku zasilania podstawowego ( $230 \mathrm{~V}$ AC) następuje automatyczne przełączenie na źródło rezerwowe i prąd płynie z akumulatora do systemu alarmowego (rys. 2a).

Akumulator nie jest w żaden sposób doładowywany przez system alarmowy. 
Analysis of reliability power supply intrusion and hold-up systems...

Analiza niezawodnościowa układów zasilania systemów sygnalizacji włamania...

Możliwa jest jednak taka konfiguracja urządzeń SSWiN (rys. 2b), podczas której występuje układ kontroli i automatycznego doładowywania akumulatora, ale nie jest on elementem składowym centrali alarmowej.

a)

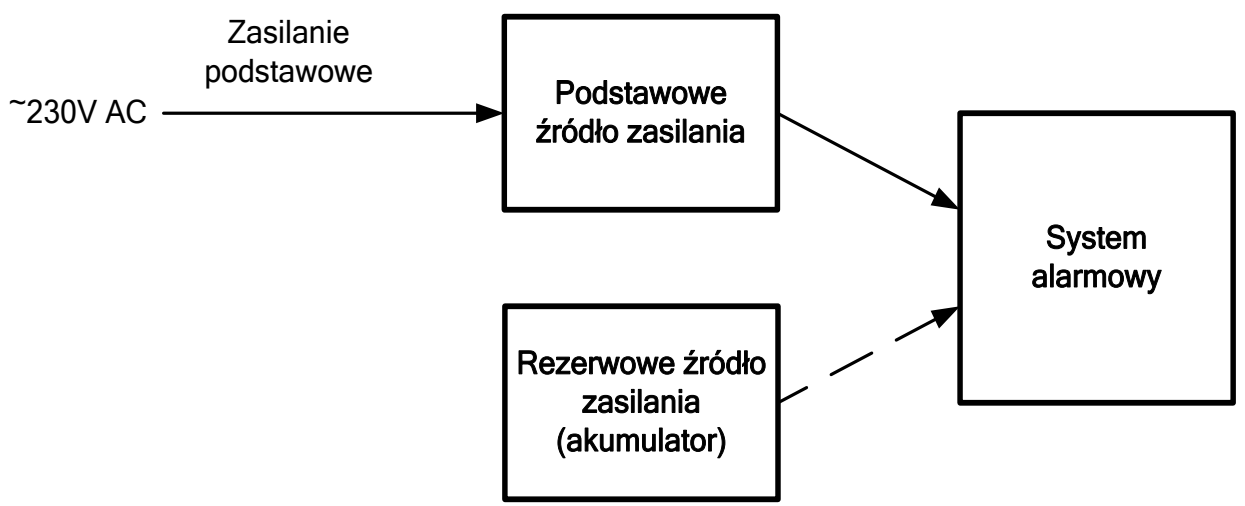

b)

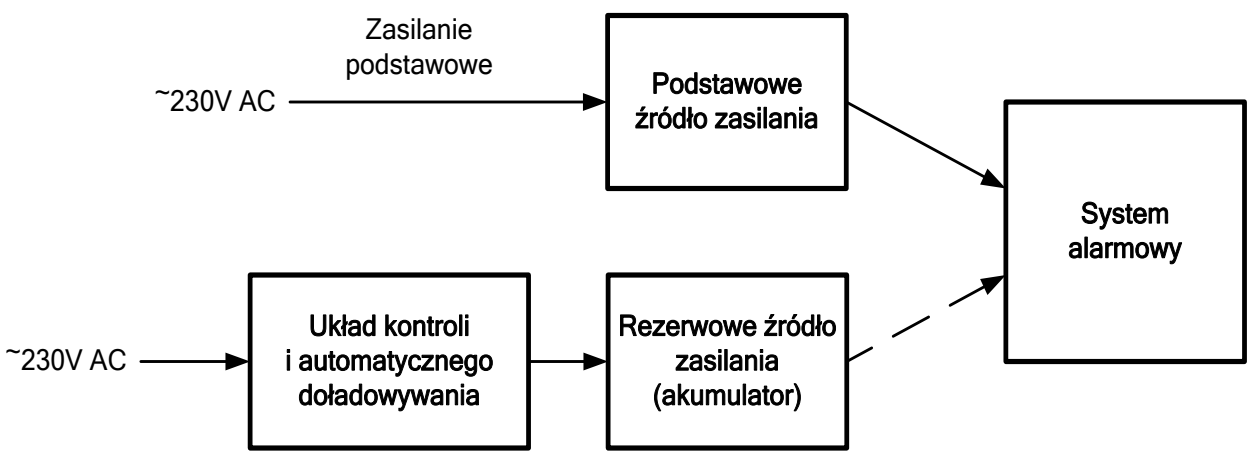

Rys. 2 Przyktad zasilacza typu B systemu alarmowego:

a) przy braku doładowywania zasilacza rezerwowego (akumulatora),

b) z kontrola i automatycznym doładowywaniem zasilacza rezerwowego (akumulatora) [źródto: opracowanie własne]

Na rys. 3 przedstawiono zasilacz typu C. Cechuje się on występowaniem źródła podstawowego o skończonej pojemności (bateria), który jest wykorzystywany do zasilania SSWiN. Takie rozwiązanie wymaga od projektanta zastosowania odpowiednio dobranych baterii, ponieważ w przypadku zmniejszenia napięcia poniżej wymaganego system alarmowy przestaje funkcjonować i spełniać zadania, do których go zaprojektowano. 


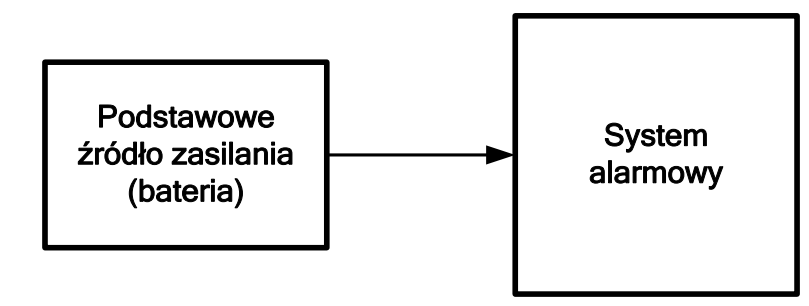

Rys. 3 Przyktad zasilacza typu C systemu alarmowego [źródto: opracowanie wtasne]

Zasilacze stosowane $\mathrm{w}$ systemach sygnalizacji włamania $\mathrm{i}$ napadu powinny posiadać odpowiednie dokumenty poświadczające spełnianie przez nich określonych wymagań i kryteriów. Dlatego też producenci tych urządzeń poddają je badaniom, które pozwolą określić, czy spełniają one stawiane im wymagania. Jednym z dokumentów zawierających wytyczne odnośnie założonych parametrów zawiera polska norma „PN-EN 50131-6:2009: Systemy alarmowe - Systemy sygnalizacji włamania i napadu - Część 6: Zasilanie". Zawarte w niej są m.in. wymagane funkcje układu zasilacza $\mathrm{w}$ zależności od typu zasilacza i stopnia zabezpieczenia. Przykładowo można podać, iż dla zasilacza typu B i 4 stopnia zabezpieczenia zasilacz powinien obowiązkowo:

- wykryć brak źródła zasilania zewnętrznego,

- wykryć niskie napięcie baterii,

- wykryć uszkodzenie baterii,

- wykryć niskie napięcie wejściowe,

- zabezpieczyć przed przepięciem,

- zabezpieczyć przed zwarciem,

- zabezpieczyć przed przeciążeniem,

- zabezpieczyć przed całkowitym rozładowaniem akumulatora.

\section{Analiza niezawodnościowo-eksploatacyjna układów zasilania SSWiN}

Dokonując analizy niezawodnościowo-eksploatacyjnej układów zasilania SSWiN należy przyjąć określone kryteria ich oceny. Może to być funkcja niezawodności, gęstość uszkodzeń, intensywność uszkodzeń, itp. Autorzy zdecydowali się jednak na wskaźnik gotowości, ponieważ umożliwia on uwzględnienie czynności przywracających stan zdatności rozpatrywanym układom zasilania. Ogólnie wskaźnik gotowości, można zapisać:

$$
K_{g}=\frac{T_{m}}{T_{m}+T_{n}}
$$

gdzie: $\mathrm{T}_{\mathrm{m}}$ - średni czas poprawnej pracy między uszkodzeniami, $\mathrm{T}_{\mathrm{n}}$ - średni czas naprawy. 
Analysis of reliability power supply intrusion and hold-up systems...

Analiza niezawodnościowa układów zasilania systemów sygnalizacji włamania...

Z przedstawionej zależności wynika, że zasilacz może znajdować się w jednym z dwóch stanów (rys. 4):

- $\quad$ stan użytkowania $\left(\mathrm{S}_{0}\right)$,

- $\quad$ stan naprawy $\left(\mathrm{S}_{1}\right)$.

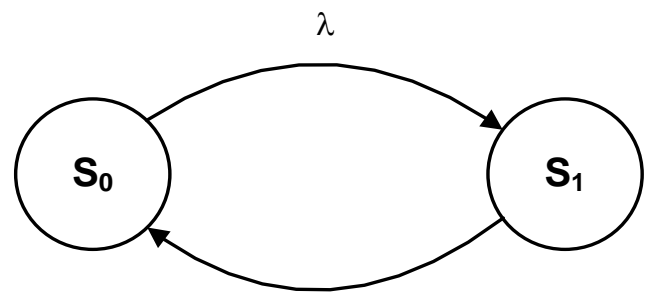

$\mu$

Rys. 4. Relacje w zasilaczu typu $C$

Oznaczenia na rys.4: $\lambda$ - intensywność uszkodzeń, $\mu$ - intensywność napraw

[źródto: opracowanie wtasne]

Przedstawiony na rys. 4 model odwzorowuje funkcjonowanie zasilacza typu C, przy założeniu że nie są podejmowane działania diagnostyczne bezpośrednio odnoszące się do stanu źródła zasilania jakim jest bateria. W przypadku diagnozowania jej stanu, model przedstawiony na rys. 4 będzie miał następującą postać - rys. 5 .

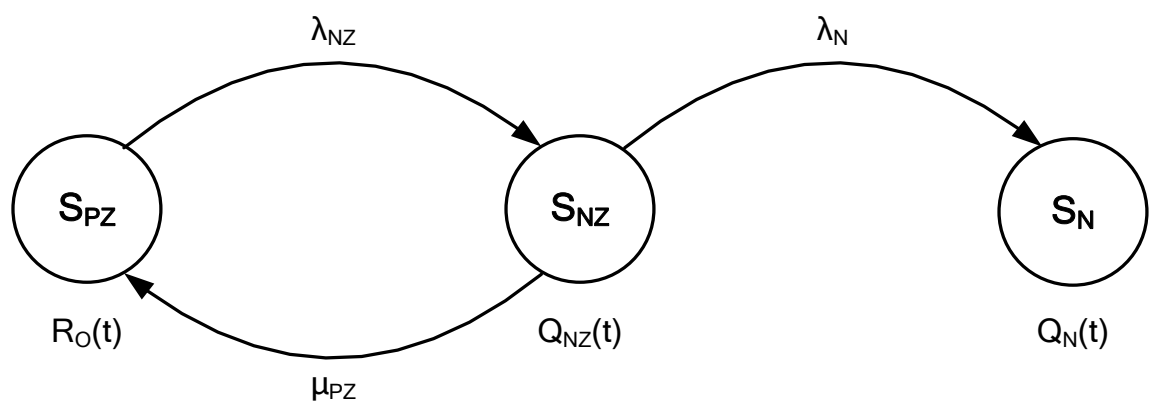

Rys. 5 Relacje w zasilaczu typu C przy uwzględnieniu diagnozowania stanu baterii

Oznaczenia na rys.5: $R_{O}(t)$ - funkcja prawdopodobieństwa przebywania zasilacza w stanie petnej zdatności, $Q_{N Z}(t)$ - funkcja prawdopodobieństwa przebywania zasilacza $w$ stanie niepetnej zdatności, $Q_{N}(t)$ - funkcja prawdopodobieństwa przebywania zasilacza w stanie niezdatności, $\lambda_{N Z}$ - intensywność przejść ze stanu petnej zdatności do stanu niepetnej zdatności, $\mu_{P Z}$ - intensywność przejść ze stanu niepetnej zdatności do stanu petnej zdatności, $\lambda_{N}$ - intensywność przejść ze stanu niepetnej zdatności do stanu niezdatności [źródto: opracowanie własne]

Analizując model przedstawiony na rys. 5 można stwierdzić, iż w przypadku zdiagnozowania częściowej zdatności baterii następuje przejście zasilacza ze stanu pełnej zdatności $\mathrm{S}_{\mathrm{PZ}}$ do stan niepełnej zdatności $\mathrm{S}_{\mathrm{NZ}}$. Wymiana baterii przez użytkownika skutkuje powrotem do stanu pełnej zdatności. 
W przypadku, gdy istnieje stan $\mathrm{S}_{\mathrm{NZ}}$ i nie nastąpią działania przywracające zdatność baterii, to po określonym czasie następuje przejście zasilacza do stanu niezdatności $\mathrm{S}_{\mathrm{N}}$. System przedstawiony na rys. 5 może być opisany następującymi równaniami Kołmogorowa-Chapmana:

$$
\begin{aligned}
& R_{0}^{\prime}(t)=-\lambda_{N Z} \cdot R_{0}(t)+\mu_{P Z} \cdot Q_{N Z}(t) \\
& Q_{N Z}^{\prime}(t)=\lambda_{N Z} \cdot R_{0}(t)-\mu_{P Z} \cdot Q_{N Z}(t)-\lambda_{N} \cdot Q_{N Z}(t) \\
& Q_{N}^{\prime}(t)=\lambda_{N} \cdot Q_{N Z}(t)
\end{aligned}
$$

Przedstawione dotychczas rozważania w niniejszym rozdziale dotyczyły zasilacza typu C. W przypadku rozpatrywania funkcjonowania zasilacza typu A, graf relacji będzie miał bardziej skomplikowaną postać (więcej stanów), ponieważ występują dwa niezależne źródła energii: zasilanie podstawowe i zasilanie rezerwowe. Zatem po analizie można zaproponować graf relacji w zasilaczu typu A w postaci przedstawionej na rys. 6 .

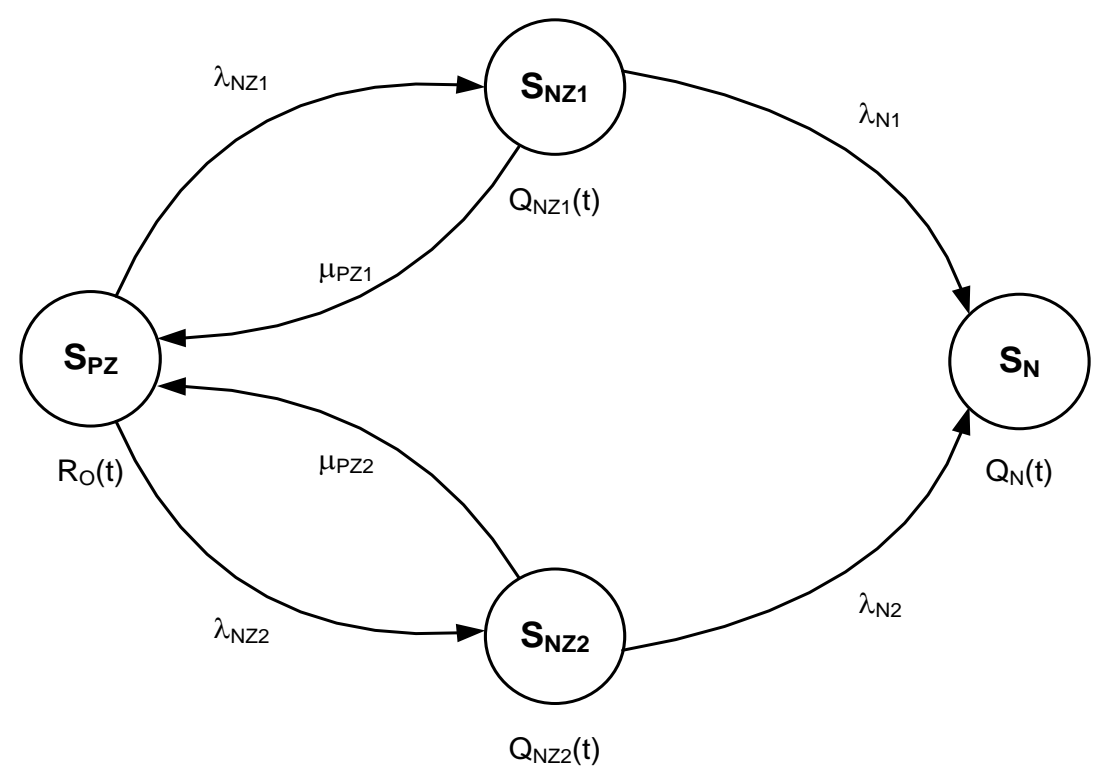

Rys. 6 Relacje w zasilaczu typu A

Oznaczenia na rys.6: $R_{O}(t)$ - funkcja prawdopodobieństwa przebywania zasilacza $w$ stanie petnej zdatności, $Q_{N Z I}(t)$ - funkcja prawdopodobieństwa przebywania zasilacza $w$ stanie niepetnej zdatności $1, Q_{N Z 2}(t)$ - funkcja prawdopodobieństwa przebywania zasilacza $w$ stanie niepetnej zdatności $2, Q_{N}(t)$ - funkcja prawdopodobieństwa przebywania zasilacza $w$ stanie niezdatności, $\lambda_{N Z 1}, \lambda_{N Z 2}-$ intensywności przejść ze stanu petnej zdatności do stanu niepetnej zdatności, $\mu_{P Z I}$, $\mu_{P Z 2}$ - intensywności przejść ze stanu niepetnej zdatności do stanu pelnej zdatności, $\lambda_{N 1}, \lambda_{N 2}$ - intensywności przejść ze stanu niepetnej zdatności do stanu niezdatności [źródto: opracowanie wtasne] 
Analysis of reliability power supply intrusion and hold-up systems...

Analiza niezawodnościowa układów zasilania systemów sygnalizacji włamania...

Uszkodzenie podstawowego źródła zasilania powoduje przejście ze stanu pełnej zdatności $\mathrm{S}_{\mathrm{PZ}}$ do stanu niepełnej zdatności $\mathrm{S}_{\mathrm{NZ} 1}$. Przywrócenie stanu zdatności zasilaniu podstawowemu powoduje przejście ze stanu niepełnej zdatności $S_{\mathrm{NZ1}}$ do stanu pełnej zdatności $S_{\mathrm{PZ}}$. W przypadku, gdy układ zasilacza typu A znajduje się w stanie $S_{\mathrm{NZ1}}$ i nastąpi uszkodzenie rezerwowego źródła zasilania, to następuje przejście do stanu niezdatności $\mathrm{S}_{\mathrm{N}}$.

Uszkodzenie rezerwowego źródła zasilania powoduje przejście ze stanu pełnej zdatności $\mathrm{S}_{\mathrm{PZ}}$ do stanu niepełnej zdatności $\mathrm{S}_{\mathrm{NZ} 2}$. Przywrócenie stanu zdatności zasilaniu rezerwowemu powoduje przejście ze stanu niepełnej zdatności $\mathrm{S}_{\mathrm{NZ2}}$ do stanu pełnej zdatności $S_{\mathrm{PZ}}$. W przypadku, gdy układ zasilacza typu A znajduje się w stanie $S_{\mathrm{NZ2}}$ i nastąpi uszkodzenie podstawowego źródła zasilania, to następuje przejście do stanu niezdatności $\mathrm{S}_{\mathrm{N}}$.

System przedstawiony na rys. 6 może być opisany następującymi równaniami Kołmogorowa-Chapmana:

$$
\begin{aligned}
& R_{0}^{\prime}(t)=-\lambda_{N Z 1} \cdot R_{0}(t)+\mu_{P Z 1} \cdot Q_{N Z 1}(t)-\lambda_{N Z 2} \cdot R_{0}(t)+\mu_{P Z 2} \cdot Q_{N Z 2}(t) \\
& Q_{N Z 1}^{\prime}(t)=\lambda_{N Z 1} \cdot R_{0}(t)-\mu_{P Z 1} \cdot Q_{N Z 1}(t)-\lambda_{N 1} \cdot Q_{N Z 1}(t) \\
& Q_{N Z 2}^{\prime}(t)=\lambda_{N Z 2} \cdot R_{0}(t)-\mu_{P Z 2} \cdot Q_{N Z 2}(t)-\lambda_{N 2} \cdot Q_{N Z 2}(t) \\
& Q_{N}^{\prime}(t)=\lambda_{N 1} \cdot Q_{N Z 1}(t)+\lambda_{N 2} \cdot Q_{N Z 2}(t)
\end{aligned}
$$

Rozpatrując funkcjonowanie zasilacza typu $\mathrm{B}$, graf relacji będzie miał postać przedstawioną na rys. 7 . W rozpatrywanej sytuacji system alarmowy nie diagnozuje rezerwowego źródła zasilania, a zatem nie jest znany jego stan techniczny (np. napięcie, poziom naładowania, temperatura pracy). Zatem istnieje możliwość bezpośredniego przejścia ze stanu pełnej zdatności do stanu niezdatności.

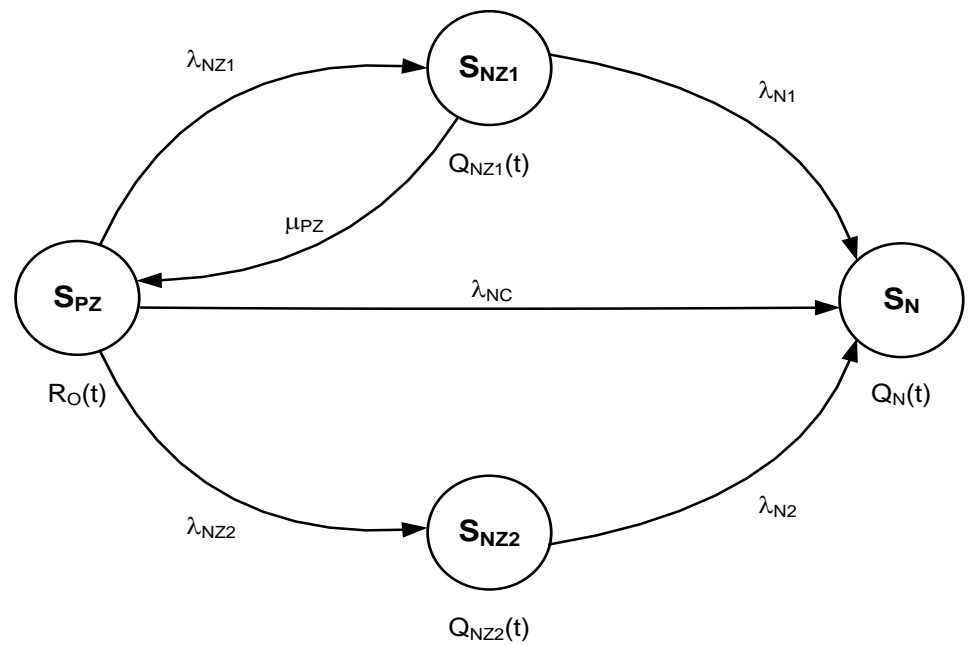

Rys. 7 Relacje w zasilaczu typu $B$ 
Oznaczenia na rys.7: $R_{O}(t)$ - funkcja prawdopodobieństwa przebywania zasilacza $w$ stanie petnej zdatności, $Q_{N Z I}(t)$ - funkcja prawdopodobieństwa przebywania zasilacza $w$ stanie niepetnej zdatności $1, Q_{N Z 2}(t)$ - funkcja prawdopodobieństwa przebywania zasilacza $w$ stanie niepetnej zdatności $2, Q_{N}(t)$ - funkcja prawdopodobieństwa przebywania zasilacza $w$ stanie niezdatności, $\lambda_{N Z 1}, \lambda_{N Z 2}-$ intensywności przejść ze stanu petnej zdatności do stanu niepetnej zdatności, $\mu_{P Z}$ - intensywność przejść ze stanu niepetnej zdatności 1 do stanu petnej zdatności, $\lambda_{N 1}, \lambda_{N 2}$ - intensywności przejść ze stanu niepetnej zdatności do stanu niezdatności, $\lambda_{N C}$ - intensywność przejść ze stanu petnej zdatności do stanu niezdatności [źródto: opracowanie własne]

Uszkodzenie podstawowego źródła zasilania powoduje przejście ze stanu pełnej zdatności $\mathrm{S}_{\mathrm{PZ}}$ do stanu niepełnej zdatności $\mathrm{S}_{\mathrm{NZ}}$. Przywrócenie stanu zdatności zasilaniu podstawowemu powoduje przejście ze stanu niepełnej zdatności $\mathrm{S}_{\mathrm{NZ} 1}$ do stanu pełnej zdatności $S_{\mathrm{PZ}}$. W przypadku, gdy układ zasilacza typu B znajduje się w stanie $S_{\mathrm{NZ1}}$ i nastąpi uszkodzenie rezerwowego źródła zasilania, to następuje przejście do stanu niezdatności $\mathrm{S}_{\mathrm{N}}$.

Uszkodzenie rezerwowego źródła zasilania (przy zdatnym zasilaniu podstawowym) powoduje przejście ze stanu pełnej zdatności $S_{\mathrm{PZ}}$ do stanu niepełnej zdatności $\mathrm{S}_{\mathrm{NZ} 2}$.

Wobec braku diagnozowania rezerwowego źródła zasilania nie ma możliwości przejścia ze stanu niepełnej zdatności $\mathrm{S}_{\mathrm{NZ2}}$ do stanu pełnej zdatności $\mathrm{S}_{\mathrm{PZ}}$. $\mathrm{W}$ przypadku, gdy układ zasilacza typu $\mathrm{B}$ znajduje się $\mathrm{w}$ stanie $\mathrm{S}_{\mathrm{NZ2}} \mathrm{i}$ nastąpi uszkodzenie podstawowego źródła zasilania, to następuje przejście do stanu niezdatności $\mathrm{S}_{\mathrm{N}}$.

Uszkodzenie rezerwowego źródła zasilania (przy niezdatnym zasilaniu podstawowym) powoduje bezpośrednie przejście ze stanu pełnej zdatności $\mathrm{S}_{\mathrm{PZ}}$ do stanu niezdatności $\mathrm{S}_{\mathrm{N}}$.

System przedstawiony na rys. 7 może być opisany następującymi równaniami Kołmogorowa-Chapmana:

$$
\begin{aligned}
& R_{0}^{\prime}(t)=-\lambda_{N Z 1} \cdot R_{0}(t)+\mu_{P Z} \cdot Q_{N Z 1}(t)-\lambda_{N Z 2} \cdot R_{0}(t)-\lambda_{N C} \cdot R_{0}(t) \\
& Q_{N Z 1}^{\prime}(t)=\lambda_{N Z 1} \cdot R_{0}(t)-\mu_{P Z} \cdot Q_{N Z 1}(t)-\lambda_{N 1} \cdot Q_{N Z 1}(t) \\
& Q_{N Z 2}^{\prime}(t)=\lambda_{N Z 2} \cdot R_{0}(t)-\lambda_{N 2} \cdot Q_{N Z 2}(t) \\
& Q_{N}^{\prime}(t)=\lambda_{N 1} \cdot Q_{N Z 1}(t)+\lambda_{N 2} \cdot Q_{N Z 2}(t)+\lambda_{N C} \cdot R_{0}(t)
\end{aligned}
$$

W przedstawionych modelach zasilaczy typu A, B i C założono, iż stan niezdatności jest stanem pochłaniającym. Porównując różnego rodzaju rozwiązania producenckie i ich użytkowanie w warunkach rzeczywistych, dąży się, aby ten stan nie był przez system alarmowy osiągnięty.

Przedstawione modele zasilaczy stosowanych w systemach alarmowych moga posłużyć do wyznaczenia zależności umożliwiających obliczenie wartości prawdopodobieństw przebywania analizowanych systemów w stanach: pełnej zdatności $\mathrm{S}_{\mathrm{PZ}}$, niepełnej zdatności $\mathrm{S}_{\mathrm{NZ}}, \mathrm{S}_{\mathrm{NZ} 1}$ i $\mathrm{S}_{\mathrm{NZ} 2}$ oraz niezdatności $\mathrm{S}_{\mathrm{N}}$. Umożliwi to wówczas porównanie różnego rodzaju rozwiązań i wyboru racjonalnego przy założonych kryteriach. 
Analysis of reliability power supply intrusion and hold-up systems...

Analiza niezawodnościowa układów zasilania systemów sygnalizacji włamania...

\section{Podsumowanie}

Problematyka przedstawiona $\mathrm{w}$ artykule dotyczyła układów zasilania systemów alarmowych. Według wytycznych zawartych w normie „PN-EN 50131-1:2009: Systemy alarmowe - Systemy sygnalizacji włamania i napadu", zaprezentowano schematycznie układy zasilaczy trzech typów: A, B i C. Dla każdego z nich przeprowadzono analizę niezawodnościowo-eksploatacyjną i zaproponowano graf relacji. Dalsza analiza matematyczna umożliwi obliczenie wartości prawdopodobieństw przebywania systemu w stanach: pełnej zdatności, niepełnej zdatności oraz niezdatności. W dalszych rozważaniach naukowych autorzy planują przeprowadzenie analiz i opracowanie modeli $\mathrm{z}$ uwzględnieniem procesu diagnozowania.

\section{Literatura}

[1] Będkowski L., Dąbrowski T.: Podstawy eksploatacji, cz. II Podstawy niezawodności eksploatacyjnej. Wojskowa Akademia Techniczna, Warszawa 2006.

[2] Billinton R., Allan R. N.: Reliability evaluation of power systems. New York: Plenum Press, 1996.

[3] Burdzik R., Konieczny Ł.: Research on structure, propagation and exposure to general vibration in passenger car for different damping parameters. Journal of Vibroengineering Vol. 15, Issue 4, 2013, pp. 1680-1688.

[4] Dyduch J., Paś J., Rosiński A.: The basis of the exploitation of transport electronic systems. Publisher Technical University of Radom, Radom 2011.

[5] Government Security Centre, National Programme for Critical Infrastructure Protection. Annex 1: Summary of critical infrastructure systems, Warsaw 2013.

[6] Kaniewski P., Lesnik C., Susek W., Serafin P.: Airborne Radar Terrain Imaging System. 16th International Radar Symposium (IRS), Dresden, Germany, 2015. pp. 248-253.

[7] Kierzkowski A., Kisiel T.: Airport security screeners reliability analysis. In: „Proceedings of the IEEE International Conference on Industrial Engineering and Engineering Management IEEM 2015”, Singapore 2015. pp. 1158-1163.

[8] Korczak D., Rosiński A.: A discussion of the reliability and performance of the power supply systems used in the airport security systems. In: the monograph „Wyzwania inżynierii ruchu lotniczego”, editor: J. Skorupski, Warsaw University of Technology, Faculty of Transport, Warsaw 2016. pp. 129-137.

[9] Lewczuk K., Zak J., Pyza D., Jacyna-Gołda I.: Vehicle routing in an urban area: Environmental and technological determinants. WIT Transactions on the Built Environment, Vol.130, 2013. pp. 373-384.

[10] Lubkowski P, Laskowski D.: Selected issues of reliable identification of object in transport systems using video monitoring services. In: „Communication in Computer and Information Science”, editor: J. Mikulski, vol. 471. Springer, Berlin Hedelberg 2015. pp. 59-68.

[11] Paś J.: Operation of electronic transportation systems. Publishing House University of Technology and Humanities in Radom, Radom 2015. 
[12] Paś J.: Shock a disposable time in electronic security systems. Journal of KONBiN, 2(38)2016. pp. 5-31.

[13] Paś J., Siergiejczyk M.: Interference impact on the electronic safety system with a parallel structure. Diagnostyka, Vol. 17, No. 1, 2016. pp. 49-55.

[14] Rosinski A., Dabrowski T.: Modelling reliability of uninterruptible power supply units. Eksploatacja i Niezawodnosc - Maintenance and Reliability, Vol.15, No. 4, 2013. pp. 409-413.

[15] Rosiński A.: Modelling the maintenance process of transport telematics systems. Publishing House Warsaw University of Technology, Warsaw 2015.

[16] Rychlicki M., Kasprzyk Z.: Increasing performance of SMS based information systems. In: „Proceedings of the Ninth International Conference Dependability and Complex Systems DepCoS-RELCOMEX", given as the monographic publishing series - „Advances in intelligent systems and computing", Vol. 286. Springer, 2014. pp. 373-382.

[17] Siergiejczyk M., Krzykowska K., Rosiński A. Reliability assessment of integrated airport surface surveillance system. In „Proceedings of the Tenth International Conference on Dependability and Complex Systems DepCoSRELCOMEX”, given as the monographic publishing series - „Advances in intelligent systems and computing", vol. 365. Springer 2015. pp. 435-443.

[18] Siergiejczyk M., Paś J., Rosiński A.: Issue of reliability-exploitation evaluation of electronic transport systems used in the railway environment with consideration of electromagnetic interference. IET Intelligent Transport Systems 2016, vol. 10, issue 9, 2016, pp. 587-593.

[19] Siergiejczyk M., Rosiński A., Krzykowska K.: Reliability assessment of supporting satellite system EGNOS. In: W. Zamojski, J. Mazurkiewicz, J. Sugier, T. Walkowiak, J. Kacprzyk (eds) New results in dependability and computer systems, given as the monographic publishing series - „Advances in intelligent and soft computing”, Vol. 224. Springer, 2013. pp. 353-364.

[20] Siergiejczyk M., Rosiński A.: Analysis of power supply maintenance in transport telematics system. „Solid State Phenomena” vol. 210 (2014). pp. 14-19.

[21] Skorupski J., Uchroński P.: A fuzzy reasoning system for evaluating the efficiency of cabin luggage screening at airports. Transportation Research Part C - Emerging Technologies 54, 2015. pp. 157-175.

[22] Standard PN-EN 50131-1:2009: Alarm systems - Intrusion and hold-up systems - System requirements.

[23] Stawowy M., Dziula P.: Comparison of uncertainty multilayer models of impact of teleinformation devices reliability on information quality. In: "Proceedings of the European Safety and Reliability Conference ESREL 2015”, editors: L. Podofillini, B. Sudret, B. Stojadinovic, E. Zio, W. Kröger. CRC Press/Balkema, 2015. pp. 2685-2691.

[24] Sumiła M., Miszkiewicz A.: Analysis of the problem of interference of the public network operators to GSM-R. In: the monograph „Tools of Transport Telematics”,editors: J. Mikulski, given as the monographic publishing series „Communications in Computer and Information Science”, Vol. 531, Springer, 2015, pp. 76-82. 
Analysis of reliability power supply intrusion and hold-up systems...

Analiza niezawodnościowa układów zasilania systemów sygnalizacji włamania...

[25] Wiatr J., Miegoń M.: Zasilacze UPS oraz baterie akumulatorów w układach zasilania gwarantowanego. Warszawa: Dom Wydawniczy MEDIUM, 2008

[26] Wiatr J.: Zespoły prądotwórcze w układach awaryjnego zasilania obiektów budowlanych. Warszawa: Dom Wydawniczy MEDIUM, 2009.

[27] Wiśnios M., Dąbrowski T., Bednarek M.: Metoda zwiększania poziomu bezpieczeństwa zapewnianego przez system biometrycznej kontroli dostępu. Przegląd Elektrotechniczny 2015, nr 10, s. 229-232.

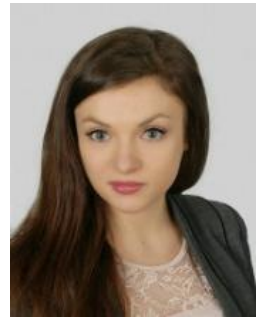

Inz. Malgorzata Pędzierska - zainteresowania naukowe wspótautorki obejmuja inteligentne systemy transportowe, ich wplyw na bezpieczeństwo ruchu drogowego oraz zagadnienia analizy niezawodnościowo-eksploatacyjnej elektronicznych systemów bezpieczeństwa (Udziat 50\%).

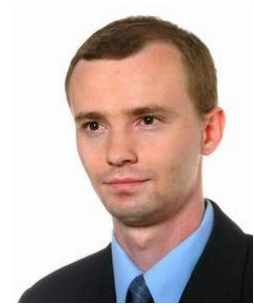

Dr hab. inj. Adam Rosiński - zainteresowania naukowe obejmuja analize niezawodnościowo-eksploatacyjng systemów telematyki transportu, inteligentnych systemów transportowych oraz elektronicznych systemów bezpieczeństwa (m.in. systemy sygnalizacji włamania i napadu, systemy monitoringu wizyjnego, systemy kontroli dostępu). $W$ dorobku naukowym posiada kilkadziesiąt publikacji naukowych (Udział 50\%). 